Leptospira icterohaemorrhagiae の電子顕微鏡的形態の研究

\author{
$\begin{array}{ccccc} & \text { 第 } & 1 & \text { 編 } & \\ \text { 基 本 形 } & \text { 態 } & \text { の } & & \\ & & & & \end{array}$ \\ 周山大学医学部碳生物学教室（指導：村上 栄教授) \\ 石井誠一
}

[昭和 33 年 9 月 1 日受稿]

\begin{tabular}{|c|c|}
\hline & 緒式 \\
\hline 第 1 章 & 実験方法 \\
\hline 第 2 章 & 実験成績 \\
\hline 第 1 節 & 一般形態に就て \\
\hline 第 2 節 & 洗滌操作が形態に及ほす影暨 \\
\hline 第3 節 & 培養時間別にみた形態の変化 \\
\hline
\end{tabular}

藉言

Leptospira の形態学的研究は，古くZuelzer (1923)1) 以来多くの研究者に依り埌告されている。 而し其の殆どが染色標本に依る䂓察的矿究で，炕無 影㓋鏡に依る分解能の限度もあり，その微細構造を 正確に把暒することは出来なかつた。

しかるに, 電子顕微鏡の出現以来, これ迄光学顕 改鏡て観察するととの不可能であつた極微細構造の 研究が発達してきて，その結果 Leptospira の形態 学的研究の分野においても電子顕微鏡に上る微細構 造阔する埌告が多くなつて，漸次詳細が明かにさ れつつある。

即ち，最近見られる主な報告は Brücke \& Haagen (1939)2), Bradfield \& Cater (1952)3), 武谷, 森 (1953)4), 北岡 (1953)5), Swain (1955)6), Mölbert (1955)7)，吉井，小野(1955)8)，川田，青井 (1956)9710， 等でその铜細構造も可成り明がなつたのであうが， 此等の報告では，各報告者閔に一致した所見むあり， 未だに異論を唱えて一致しないものもあり，結局は 種々翼つた所見が得られている状態である。

即ち、 Leptospiraは1本の緎維所謂軸糸上，これ を取巻く原形質体からなるということは一致した所 見であるが，Leptospira の被膜及び粘液外層の存 在，及び構造，並びに原形啠体内部等の棈造に関し ては末だ異論のある所である.
次

第 4 節 形態に及にす各種条件の検討

第 5 節 超薄切片に依る锤察

$\begin{array}{rr}\text { 第3 章 } & \text { 考 按 } \\ \text { 結 語 } \\ \text { 文 献 } \\ \text { 与真説明 }\end{array}$

而して此等の相買は，䒠験に使用する拣の羑猉に 依るものか，或は培梠㷛件の差哄に依るむのか，其 の原因となるるのは全く不明である。

著者も Leptospira の棈造を明加沉する目的て， 茲数年来 Leptospira icterohaemorrhagiaeを用い, 最も普通にみられる正常形態を超莎切片法と併せて 電子顕微鏡に依り钲察したので，その結果に就て報 告する。

\section{第 1 章 実 跧 方 法}

実験に使用した Leptospira icterohaemorrhagiae は，高知爆衛生研究所から分与された怢であり，培 養には纉て Korthof 培地を用い， $25^{\circ} \mathrm{C} \sim 27^{\circ} \mathrm{C} に$ 4 週間培獈後, 次代継代を行つた。

電子顕溦鏡試料の作製法は，一般的にはLeptospira icterohaemorrhagiae の增殖している培養波を， 1500r.p.mで20分間溒心猚し，此の上清を6000r.p.m で20分間再び遈心沈測後，其の沈渣を元の量まで燐

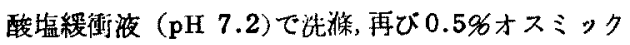
酸燐醉楥衙液（pH 7.2）に再浮遊し，室温で再度 6,000 r.p.m て20分間堂心沈澱しつつ固定し, 沈渣 を再蒸溜水で再び遠心沈腶洗淮後，再蒸溜水に浮遊 して其の一滴を，或は更にもう一度此の兟涤操作を 繰返えした後の一滴を、コロヂウム膜上に载せて乾 燥する方法である。

かくして出来た陚料をそのまま，或はCrshadowing 
を行つて籍子顕微鏡で鏡槙した。

超薄切片武料は東 (1952)11) に準し，前述の如く 固定洗涤した沈渣を，アルコール系列中で脱水する のであるが, 20\%アルコールから始めて無水アルコ 一ルに到るまで，各濃度アルコールを30分宛行い，

Monomer-alcohol 等量液に室温中で 1 時間，次いで 新たな Monomerで夜漫漬。しかる後カプセル内 に各 Leptospira 塊を入れて, Monomer に依る重 合を $45^{\circ} \mathrm{C} 8$ 時間行つて包埋したブロククを作製し た.

Monomer は, n-butyl methacrylate $と$ methyl methacrylate を季節に応じて多少変えたが，平均 7 :3の割合に混合し, 重合促進剤の benzoyl peroxideは2\%の割に混合した。

切片を作るに当つては，日本ミクロト一ム製 $\mathrm{RU}$-3 型を使用, 切断された各切片は40\%丁ルコ 一ル液面上に受けて後, $60 \sim 70^{\circ} \mathrm{C}$ 湯にて切片のし わを延ばし、コロヂウム膜を張つたメっシュに载せ 脱包埋することなく観察試料とした。

尚, 使用電子顕改鏡は日立製作所慗 $\mathrm{Hu}-6$ 型及

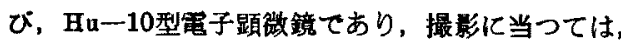
加速電圧 $50 \sim 75 \mathrm{KV}$ ，電子電流 $100 \mu \mathrm{A}$, 直接撮影 倍率5000倍の条件下で雟察した。

尚, 電子顕微鏡的観察之併行して，暗視野装置に 依る鏡検及びギムザ染色儿依る光学像的観宗も行い， 常に比较検討しつつ実験老行つた。

以上が実験方法の概略であるが，特殊な操作を行 つた実験の詳細に就ては，其の都度説明を加えると ととした。

第2章実酸成績

第1節 一般形態汇就て

前述の実験方法に依り镜察した Leptospiraの一 般的形態は，写真 1 亿見られる如く，1本の直線的 な轴系を菌体部が螺损状仅取卷いた形態を呈する場 合と，逆に写真 $2 ， 3$ 及び 4 に見られる如く，軸系 が菌体部の蝶搪に沿つた形絮を呈する場合とがあり， 前者は少数認如られ，後者の方が多〈認められる。

而して，後者の場合，軸糸は菌体部の画端に近つ” く部分で鮮明であり，中央部では画体中に幾分入つ ている為に諗め難いのが普通である，又軸系の大さ

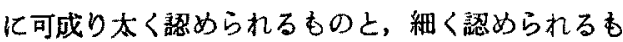
のとの差異があるが，これは Leptospira の個体差

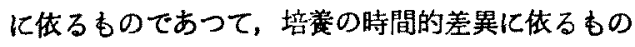
で仿ない.

次に，菌体部又は原形質部であるが，一般に太く，

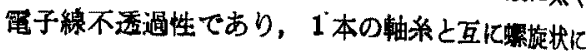
㨝れ合つていることは前述の通りで，両端部に近う くに従つて細くなつている。

此所で問題になるのは，写真 5 に見る如く，菌体 末端部で菌体自身が不規即なる塊りを作つた像を 々認めることである。原因は不明であるが，生きた Leptospiraなることは確かである。

次は被膜に関して，Leptospira の菌体を取用ん で存在するすのなりや否や，若し存在すれ活更湖 系をも取巻くものなりや否や，というととでるが 其の判定は甚だ困難であり，乙れは超薄切片几依る か, 或は化学薬郕を用いて菌体を徐々汇破填してい くか，何らかの方法に㑈つて確めない限り不明であ る.

第 2 節 洗旗操作が形態伅及活す影算

铔生物の電子顕徽鏡用試料の作製儿際しては，前 述の如く遠心沈泚法に位る洗滌操作を必要とするて とは常識であるが，功る洗浨操作倍依る物理的作

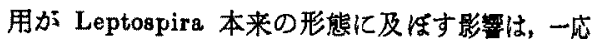
考虑されなければならないものと考元られる。故伔 此の種の影響の有無を知る為に，次の実跧を試みた。

即5，Korthof 培地に培美 1 週間目の6のに訊て，

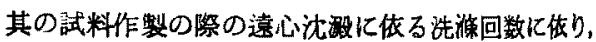

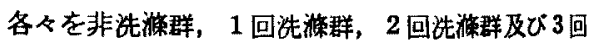
洗旗群の 4 種類の群に分けて, 其等の間の形態の相 運を比较観察した.

非洗济群とは，Leptospira の增殖している Korthof 培羡液の一白金耳を取り，直接コロヂウム獏 上に载せて乾燥させたるのを，オスミクク酸蒸気固

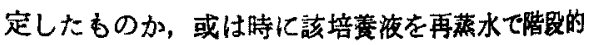
に倍数稀积したるのの一白金耳を，同样固定したも

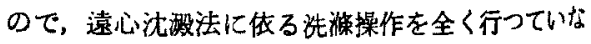
い試料である．他は全て洗满回数に依り，夫々1回 洗㳜群, 2 回洗湺群及び 3 回洗淮群等とした。

写真 1 は，培羕 6 日目の韭洗使試料稘てちり，写 真 2 は，培美 7 日目の 1 回洗溁試料像でる。一般 的には，Leptospira は此等の像に見られる如く， 細い1本の軸系之螺旋状江迴転している原形梊体と が互に接れあつている形態である。但し非洗湤群の Leptospira には，菌体の外側周囲に更に官子線委 過性で粘液椂物筫から成ると思执机外首を有して いるものが多く見られる。 此の外層の認められる頻度は，各群50值宛の蜘祭 に於て，非洗湅群中には39個，1回洗澡群中に2 個 


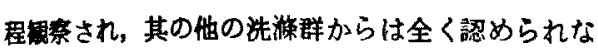
加大.

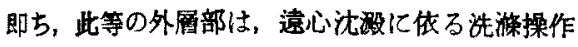
の如き注勿諭，極くわずかの物理的作用に依つても 容易化脱落する。但し、非洗涞群中にる，乙れの認 められないものが少数存在するのは，試料作慗の際

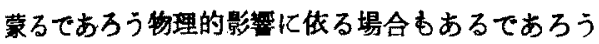

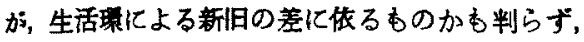
又、とれは果して完全なる棰造の一部をなすすのか， 或は箪に Leptospira 加ら分泌された分泌物の沈滞 附着しているすのか関しても不明である。

第3箅 培楼時間別にみた形態の変化 Leptorpira の培養 2 週目のものを, 新たに Kor-

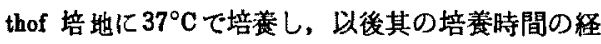
過行往つて50個つつの Leptospira 亿就て，7 日目

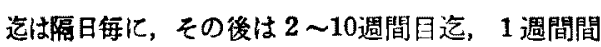

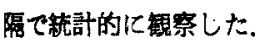

其の結果，粘液外層に関しては，やはり非洗淮試

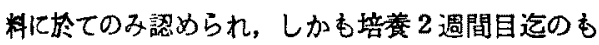
のにのみ多く認められ，其の後はその数を急激に減 し，5週間目以後の試料には殆ど認められなかつた。 要するに発育の盛んな幼若体汇のみ多く認められ るあのでててれを Leptospira の構造の一部と見な し難い.

写真 1 は，培 6 日目のむのであり菌体部は電子 線不透過性の物質が旮渶されている。

写真 2 及び， 3 は，培養 2 週間日のものであり， 写真 4 は 3 週間目のものである。菌体部は次第化湅 長くなる感しを与えるが，尚不透過性物質が充満し ている. とてろか培翊 4 週目頃の試料中には写真 5 の如く，菌体の末端部に不規則な塊を形成している あのが見られる、この塊は一端のみにみられる場合 ああり，又兩端に認められるすのもある，ての様な 形惄変化を示す頃は，菌体部電子線透過性を增し てくるし，螺旋度も緩るくなつてくる．更に原形倎 の次第に多くの細片状䋼れを生してきて，後には不 定形顆粒状化してくる. 細菌体内原形質の变化と全 く同粐である。

写真 6 は， 6 週間目の Leptospira で，更に陳旧 化が進み遂住己融解が起つてきたとてろを示すす のでる。菌体はわずか原型を停めるだけで原形

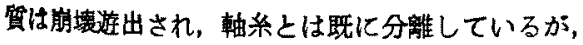
原形賈の崩壊に比して軸系の崩壊はかなり遅く，細

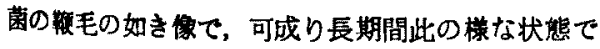
みられる。
写真 7 も 週間目のむのであるか，崩壊していく 菌体の原形䆩と軸糸とが，游離していく状熊をよく 示している．軸杀の両端のみは橉体原形質内に埋む れていて，軸系の両端は膨大して闌体中にあるよう 梽感じがする。

此の事をよく示したのが写黄10である．更に陳旧 化が進んで8週目になると，写真8に示す如き像がよ く見られ, Leptospira の原型は全く認められす軸系 手細切されているが遂には消失してしまうであろう。 10週目の試料中には写真 8 程度のあのが多くみら れ，写真 $6 ， 7$ の如きすのみられる，それ以後の 観察は困難であり，統計的に表わすわけにゆかなか つた.

写真 9 は，既に述へた末端の不規即塊を作る前兆 とむ考元られ，伸びきつて蝶旋状娊を失つた菌体部 の原形質は，军真 5 の如き，多くの顆柆状汇陳旧化 した時，顆粒と顆粒との間の部分で折れ曲つて，か くの如き塊を作る粎である。

写真11も，此の不規則塊を示すが原形質部を取巻 く被膜の存在は明かでるる。

写真12及び13は，陳旧化した Leptospira の試料 中に時々見られる像で，原形質は顆粒化した部分で 切断された形で，一連の形態をなしているが，てれ が単なる人工産物か否かは，解釈困難なところであ る.

以上の如き過程を経て，陳旧化後自己融解してゅ く事は判つたが，其の他非常に多くの試料を観察し てみても，どうしても Leptospira の分裂增殖像索 つかまえることが出来なかつた．又現在迄 Leptospira の分裂像を示した辄告も皆無である.

果して如何なる機模依り，分裂增殖していくも のかの研究は尚、今後の問題である.

第 4 節 形態に及任す各種条件の検討

電子頙销鏡用試料の作製には，多くの操作を必要 とするととは勿論であるが，就中，逗心沈激㙅作が 大なる影曏を与えるととは勿論で，粘液外層の锶察 では特に重要なることは既に述へた。

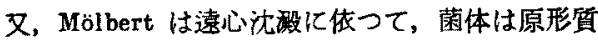
部あ顆柆状塊片となることを述べている。こで各 種培盖時間の! Leptospiraに就て，趣転数を1000r.p.m, 1500 r. p. m, 2000r. p. m, 3000r. p. m, 5000r. p. m, 及び 10,000 r. p. m と変え, 迴転時間をいずれも30

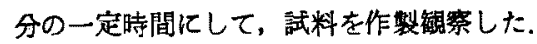

その結果は培養の浅い Loptoopiraでは, 顆粒状

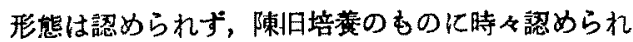


たが，てれも同一視野中にも，健全な形热のむのと 顆柆状形態のものとが混在しているのがみられた。

故に，てれは Leptospira の陳旧化に伴う現鮽で あつて，遠心沈撒による産物ではいととが判つた。 但し，10,000 r. p.mの6のでは，多少螺旋数が 少くなつて，伸びた形を呈するように思われたが， こ机む正確に表わすのは困難である.

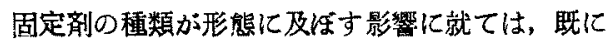
0.5\%乃至1.0\%のオスミック酸が最良のものである ことは周知の事であるが，二の他のアルコール及び， ホルマリンに依る固定及び非固定の試料に就ても比 較してみた。

この結果，非固定試料とオスミック酸固定試料と の間には，表現する程の差異は認められないようで あつた.

アルコール固定㻅料は，試料が鮮明さを欠く恐れ があり，ホルマリン固定では，尚更鮮明度を欠ぎ， 幾分収縮した感じす見受けられた。

てれは技術的まずさむあるのであろうが，結局は， オスミック酸固定法に依るべきであるとの結論に達 した.

次に，Leptospira が示す蛿旋形態が，電子顕微 鏡像及び光学頚微鏡像之暗視野到徽鏡像との間に, 可成り差異を示してみられるのは，暗視野像は生き ている状態を観察しているのであり，他の 2 つの像 は死んだ材料を，しかも乾燥させて後顴祭すること に拣り生ずるすのである事が考えら机る。

第 5 節 超薄切片に依万観察

Leptospira の超薄切片による铎祭はその䋛断面 及び棤断面を観察し, 菌体内棈造, 特に軸系の位置 及び被膜の存在を確認する目的で行つた。

写其14は，培羡 3 週間目の Leptospira の維断像 で，電子密度の高い蚝旋菌体部の中央を，1本の軸 糸が一賁して走り，その軸系の周围に平行して一連 の透過性部分が存在し，恰香細い筒の中を 1 本の軸 系が，一側に片寄つて通つている如くみられ，又， その筒自身が菌体中を更に賁通している如くに見ら れる。しかす，此の状態は Leptospira の中央部の みに見られ，両端部では認め難い。

即ち，切片にしていない一般の試料の場合には， 軸系は前述の如く，菌体中央部に於ては，外部加ら は認められず，両端部でのみ認められる。

結局，中央部䎲於ける軸系は此の椂な状態で皃体 中を走つて存在しているてとが判つた。

写真15も同様の所見である.
写真16及び17は，其等の横断像て，菌体の棈断面 には，電子密度の高い原形質部中に空胞状の部分か おりそその中の片側に寄つて更に電子密度の高い輔 糸の偏在しているのが認められる。

写真18及び19は，培盖 4 週目の Leptospira で, 写真18は縦断像であり，原形質部之薄い被膜と性完 全に雕れて，幾分陳旧化しているのを示す。

写真19は，横断像及び斜断像が混在してみられ， 又菌体中央部を示寸像もあろうし，末端部を示す像 も存在するのであろう．被膜の存在を確認するとと は出来るが朝系に就ては，はつきり云うわけに仙必 かない.

\section{第3章考按}

Leptospira の電子顕微鏡的形恁学の研究報告仕

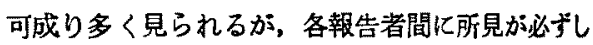
も一致していないことは，試料作製法仁各自差異の あるととと、 又 Leptospiraの発育時期纴生活骤 の相巽等種々の条件仪支配されるものであ万うてと が考えられる。

著者は試料作紫传当つて，Leptospira が蒙るて あ万う種々の影響を最少限に停めること亿努め，自 然のままの形態を保持し，人工産物の出現を極力阻 止する為に，固定にはオスミック酸橉酸緩㣫液を用 いて実験を行つた。

得られた各部分の形態に就て考按を加えることと した. Leptospira icterohaemorrhagiae の中央沉椋 1 本の䄉維が見られ，乙の名称に関して吉井等， Swain，及び川田等は軸系と称し，Czekalowski (1955)12) は Axistyle と称し, Bradfield 及び Mölbert は䄉維又は峨維束と称している. 勿論此等 の名称䎲就ては，分類学的見地加ら尚詳論の余地汃 あるようであるが，こてでは別殿深い意味を含まず 単に軸糸という名称を用いるとととした。

此の軸系は幼若な Leptospira では 1 本の比校的 真值な䋐維であつて，乙れを菌体が立体的蝶挍状化 取巻いて更にその両者を薄い被膜が包んでる，而 して電子顕微鏡像では試料作製の際の乾燥に㖪り， その存在は一層明瞭に認められる。軸糸は Leptospisa の両端部に於て比較的見易く，末端部て仗原 形質部内に穿入して終つている，中央部では原形算 部内を贯走しているので外観上見るととは出来ない。 此の事を述へた報告者は 1 人す無いが，彼等の示 している雪子顕钽鏡写真は，全て此の像を示してい るのに，斯くの如く述へていないのは如何なる理由 
飞依るのてあろうか。粙紋は陳旧化に伴う変化が菌 体部分に比较して少く，菌体の自己融解後も尚 1 本 の緹維として永く遊離存在している。

次に粘湤外首部の存否及び棈造物の一部なりや否 やに就ては，最近吉井等及び川田等の報告で互に論 していて今尚問題となつている。

著者の実倹結果加らは，非洗莱陚料汇於て上く認 められ，わずか加加えた操作上の影響でも容易に脱 落し，又特に幼若なむのに多く見られる事などと， 多数試料を银察して得た経験加ら差程大きなるので なく，てれは細菌似於ける粘液層に相当寸るものの 如く，構造の一部と解するわけにはゆかなかつた。

被膜に関しては細胞周辺にある構造粎膜と Morton (1943)13)が述へ，又透明部之いう名称で 富棈等 (1950)14) が述べているが，武谷等、Swain 及び川田等も大体被膜或は細胞膜の如きすのとして 存在を認めている. 然し名称がこのように種々巽る のは其の存在が判然としていないからであろう。 又 吉井等は単に細胞体之軸系とを粘液層が包んでいる と述でている．著者の超薄切片像からは明かに被膜 を認めており，これはむしろ細胞膜と述へた方が適 当であるように思われる，軸系と被膜との関係の詳 細は更に実験を行つてから述べたい，

原形質部は螺揟状を呈していて，陳旧化に伴う透 過性の変異を起す点では細菌類と全く同じである。 ただ陳旧化仁伴い各所で切断された多数の顆柆状原 形質塊として認められる場合のあるのを，Mölbert は遠心沈澱操作に依る人工座物であると述へている が，著者の検討したところでは同一条件下保作し た試料であ，此等の像恃時々しか認められず，単に 陳旧化汇伴つて起つた現象であって，人工産物であ ろうという意見には反対である。

次江終未糸という形態学的名称化就ては，現在尚 明確にされていない，つまり概念がはつきりしてい ない為であ万，Leptspira の電子影微鏡像に於ては 北岡及び武谷等は終未系を認めていないが，吉井は L. mochtari 飞於て其の両端部にやや起大した部分 を認めている，著者も此の膨大部を認めてはいるが， てれを終末系之呼ぶかどうかは疑間任思つている。

要するに Leptospira の軍子顕微鏡的微細構造の 研究は，多種多様の所見と多くの異つた名称の存在 滍わされるとてろが多い. 然し乍ら著者の実験か ら得られた結果を，あまり名称にてだわらずに述へ れで, Leptospira icterohaemorrhagiae の示す形態 は，最外侧に粘菠層があり，その内側に薄い被膜が
あつて，1 本の軸系と蝶旋状の原形質体部が主体を なして包ま机ていて，軸糸は菌体中央部では原形質 中を走り，両端部では原形質外部走走り，両末端で は膨大して原形質に移行している，乙れ迄の多くの 報告中の或るものと一致する所見もあるが，或るる のとは相反する結果を得た次第である。

結語

Leptospira icterohaemorrhagiae 地に培羡し，電子顕徽鏡的形態鹳察を行い次の成績 を得た。

（1）Leptospira の最外側には巾の狭い粘液層が 存在し，これは細菌の粘液層に相当するむので，培 養の比較的浅い奻若なすの儿多く見られ，試料作彆 時に加わる，わず加の作用であ容易に脱落し，これ が Leptospira の構造の一部であるとは考えられな かつた.

（2）Leptospira の菌体部は，乙れを包む被膜が 存在し，超薄切片試料に依り一層明かに見ることが 出来る。つまり切片以外の標本では乾燥代依り受け る影響むあつて，その判定は困難なる場合が多い。

（3） 1 本の軸系が蝒㳬状菌体部に沿つて立体的に 存在し，菌体中央部では原形犋中を走り，両端部で は外層に出て原形質外部を走っている，そして其の 末端部では膨大して原形質に移行していることが判 つた。

（4）菌体中央部の軸糸は，原形質部内を細い管状 を思わせるような空胞性の中を，片方に偏在しなが ら走つている。

（5）菌体部を構成する原形質部は，電子密度は高 いが，陳旧化伴つて濃焱を生してきて，時に顆柆 状㳊細切される場合もある。

(6) Leptospira は培㽰時間の経過化伴つて陳旧 化し遂には自己融解して，原形質及び被膜の区別は 然くなつて了うが，軸系の融解は遅れて，其の後も 尚游離した状態で割に永く存在する。

（7）Leptospira の分裂像を認めるてとは出来な かつたが、此の目的の為には今後特別なる培䓹法を 考虑する必要があるのではなかろうか.

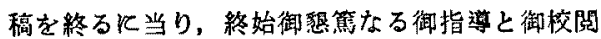
を睗つた村上栄教授飞対し又御支援を戴いた传助教 授に心から感謝の意を表する次第である。

(尚此の諭文要旨は第 9 回日本細菌学会中・四国 支部総会飞於て発表した） 
文献

1) Zuelzer, M. - Prowazeks "Handb. d. Path. 1955.

Protozoen", Bd. 3, 1628 1798, 1923.

2) Brücke, E. \& Haagen, E. · Naturwissenschaften, 27, 809 811, 1939.

3) Bradfield, J. R. G. \& Cater, D. B. . Nature, 169, 944 946, 1952.

4）武谷，森 日新矤学，40，607 611，1953.

5) 北岡: 科学, 23, 38 41, 1953.

6) Swain, R. H. A. . J. Path. Bact. 69, 117 128, 1955.

7) Mölbert, E. : Z. f. Hyg. Infek., 141, 82 90, 1955.

8）吉井, 小野: 東京医事新誌，72，449 450,

$$
\text { 写基鮵 明 }
$$

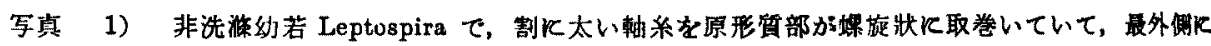
透過性の站液栏物質の附真しているのを示す。

写真 2）3）4）粙系は菌体中央部では見られず両端部で可成り外層部に見られ，末端で再び 原形舅中に入っている。

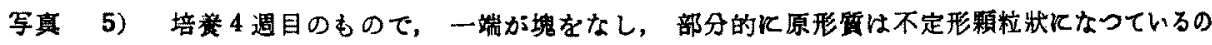
を示す.

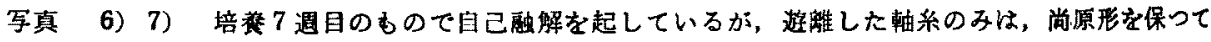
いる，7）火於ける軸系の末端は膨大して原形出に移行しているのが判る、

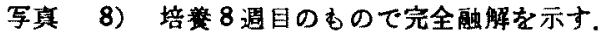

写真 9）陳旧化に伴い蝶旋狀態は全く認められない。

写真 10）軸系末端部と原形質の関係を示す。

写真 11) 端部の䝵狀を示す。

写真 12）13）陳旧化して原形質が細片に崩塤しているのを示士。軸糸は見えない.

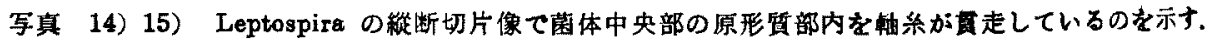

写真 16）17）横断切片像で空胞様内部の片方飞軸系の存在しているのが思られる.

写真 18）19）陳旧化した Leptospira の横断，縦断及び斜断像で被膜の存在る示す. 


\title{
Studies on morphological characteristics of Leptospira icterohaemorrhagiae by electron microscope
}

\section{Part 1. Studies of elemental structures}

\author{
By \\ Seiichi Ishii \\ Department of Microbiology, Okayama University Medical School \\ (Director: Prof. Dr. Sakae Murakami)
}

By means of the electron microscope, the futher studied the morphological characteristics of Leptospira icterohaemorrhagiae that was grown in tne Korthof media. And the following findings were observed.

1) There was a thin slime layer on the surface of the organism. This layer might be supposed to correspond to the slime layer of bacterium, was frequently found on the organism of young Culture, and was fallen off easily by careless handling furing preparation.

2) The body of the organism was covered by a membrane. The membrane could observe easily and clearly on slices made by ultramicrotome. Otherwise, it could hardly identify the membrane by occurence of desiccation artifact.

3) The organism had a well definded axis filament along its slender body in the following way. In the middle part of the body, the filament was mounted in cytoplasm; Near the both ends, it was appearenced over the surface membrane of cytoplasm. and finally at the ends, it became thick and entered again cytoplasm.

4) The filament mountes in cytoplasm run through the small canal, and moreover it situted in eccentric position.

5) The cytoplasm constituting the body of organism had high density for electron beam, but as the culture elapsed it became inhomogeneous, and occasionally it was slit into several granular masses.

6) The cytoplasm and membrane of the organism gradully disintegrated by autoloysis as the culture elapsed: However, the axis filament remained still longer without to be autolysed.

7) It could not be detected the divission-figur of the organism. 
石井論 文附 図
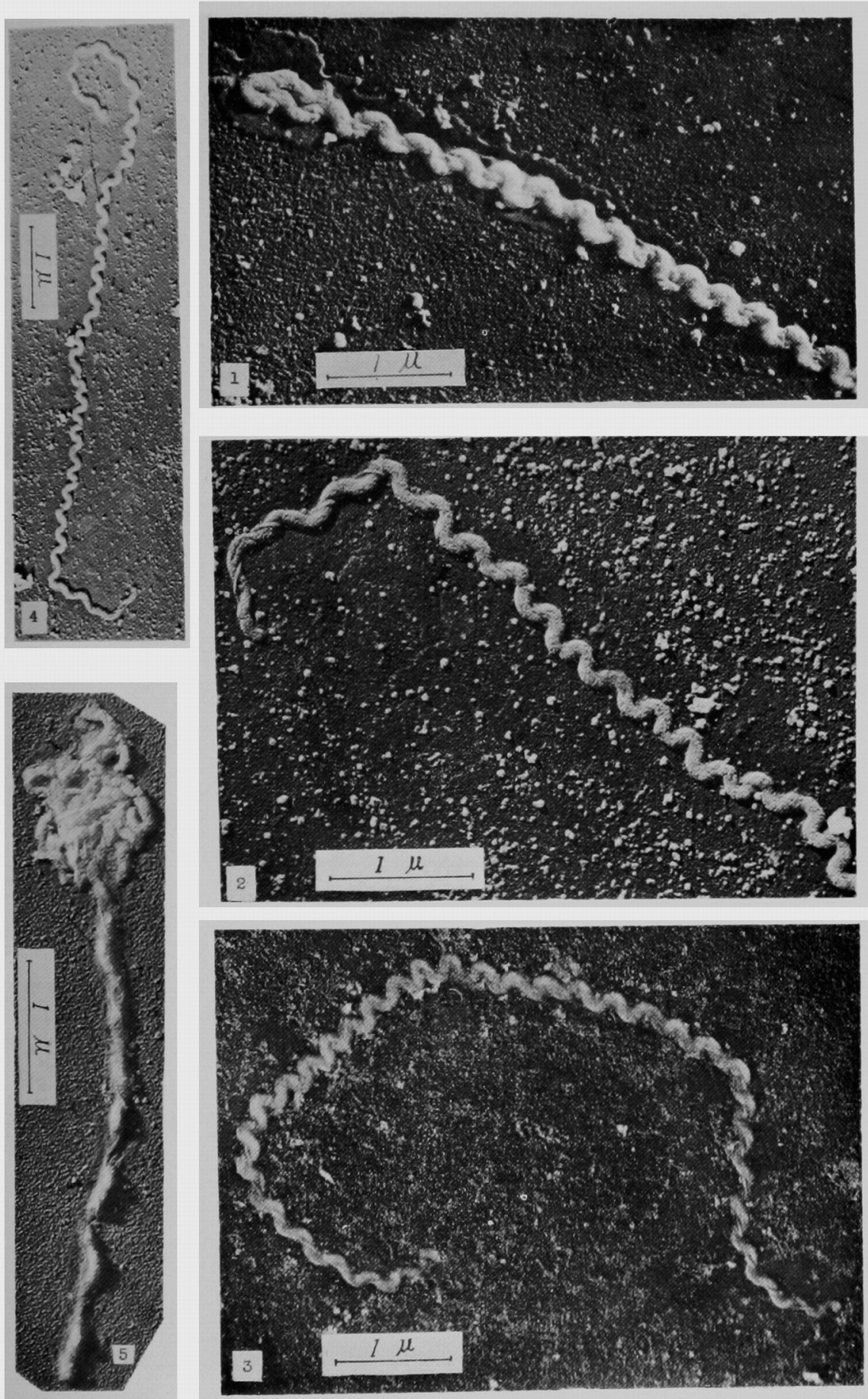
石井論文附図
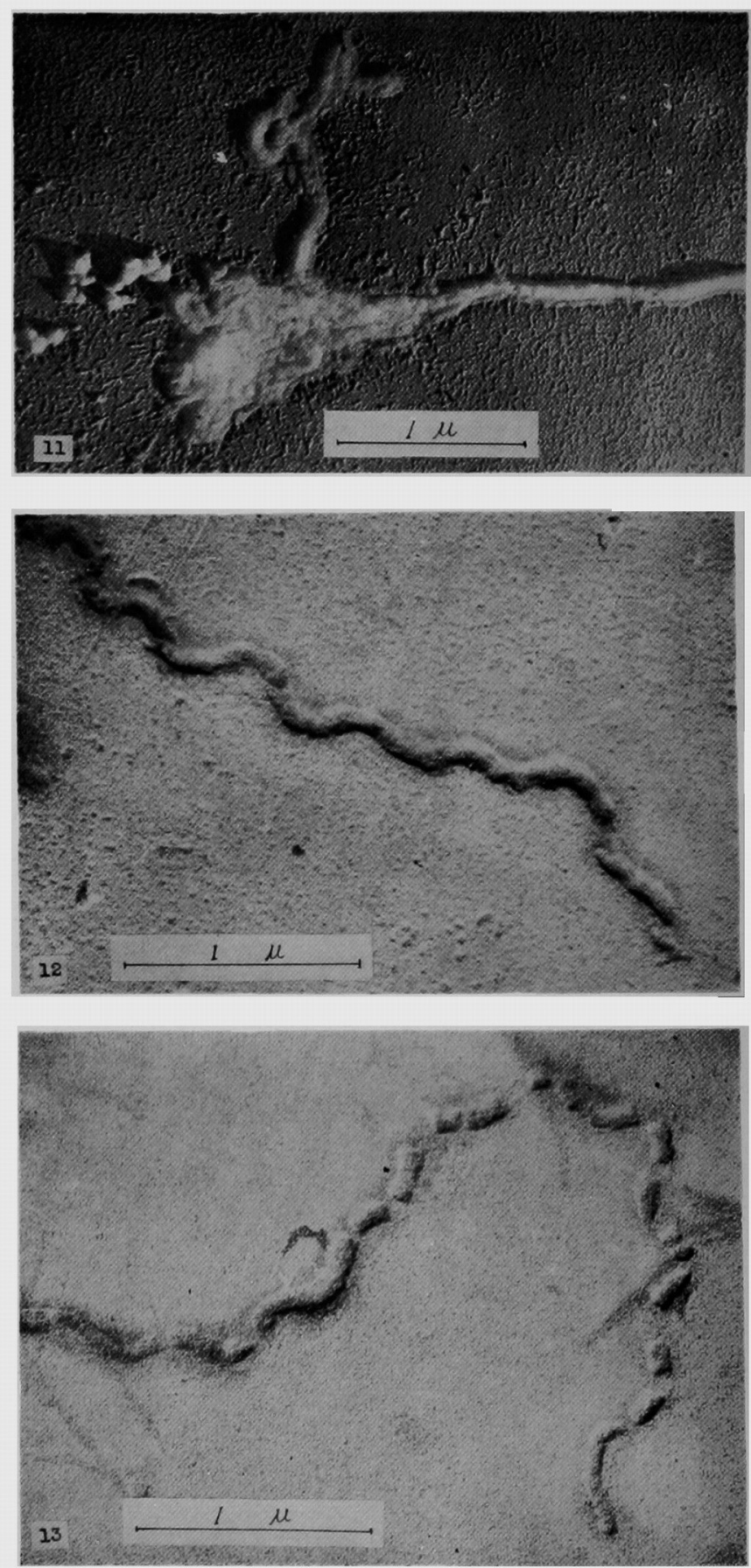
石井論 文 附 図
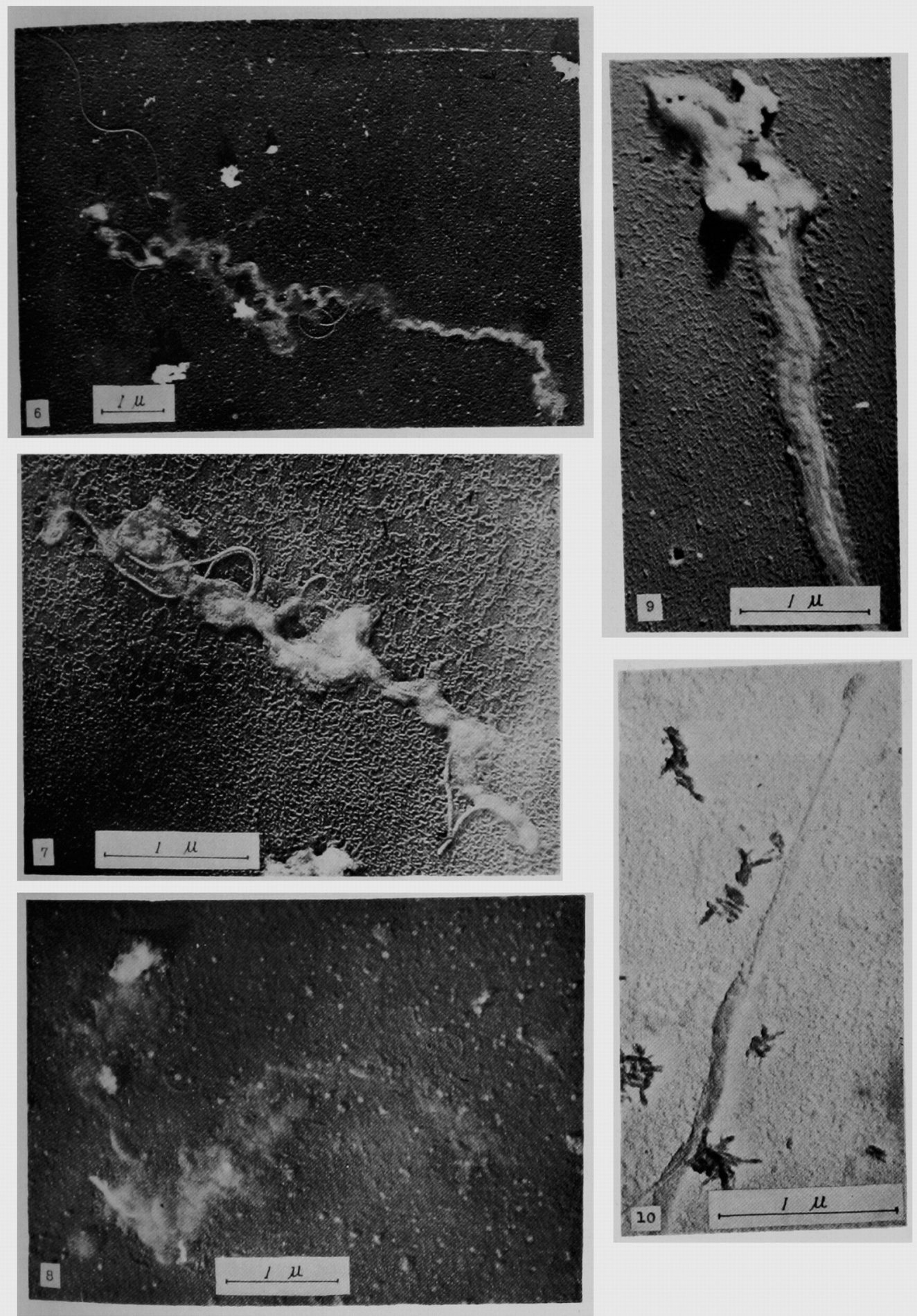
石井蹁文附図
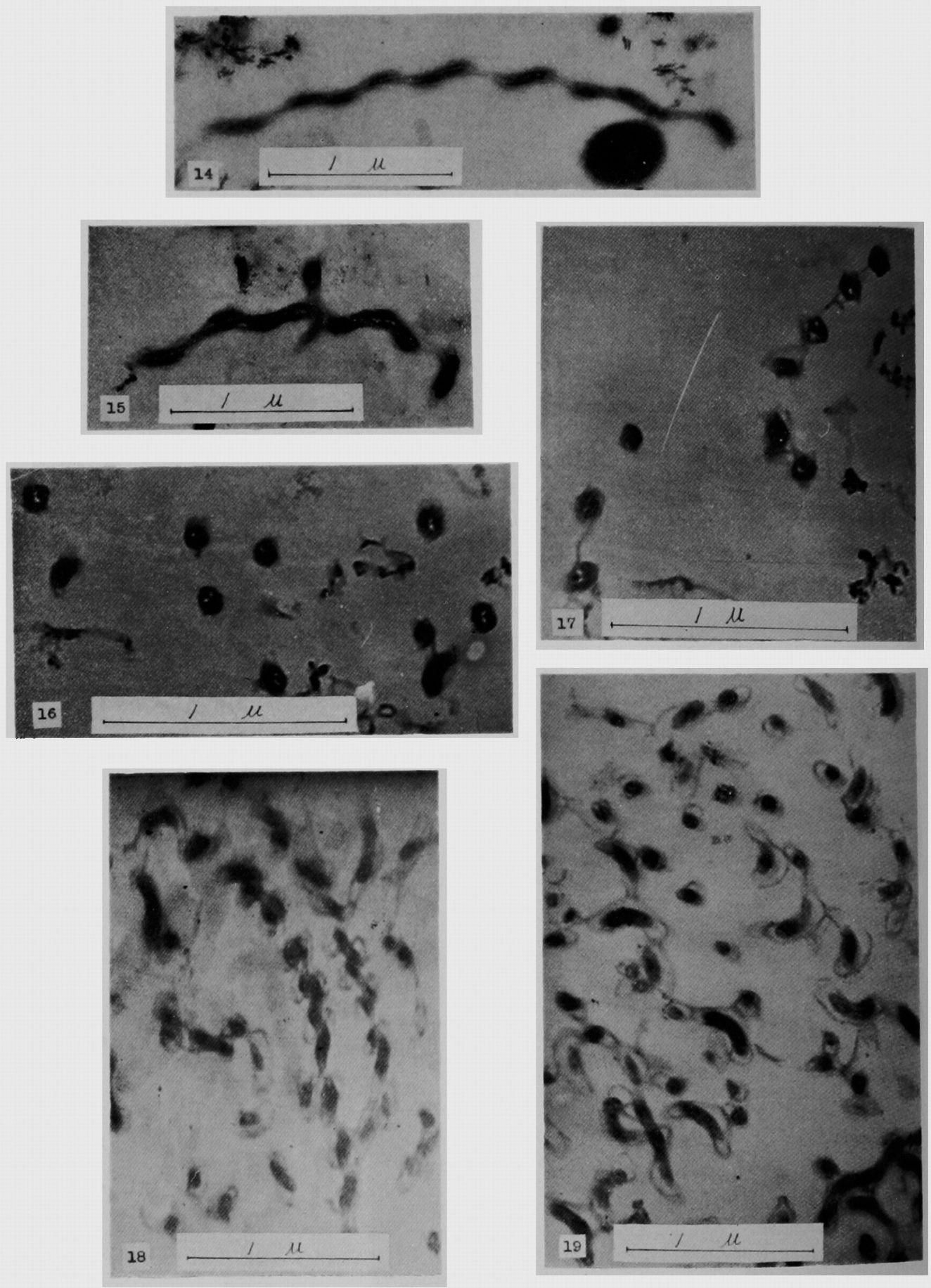